\title{
Hubungan antara Modified Glasgow Prognostic Score (mGPS) dengan Stadium dan Derajat Diferensiasi Kanker Ovarium
}

\author{
Bob Irsan¹, Heru Pradjatmo², Muhammad Lutfi ${ }^{3}$ \\ ${ }^{1,2,3}$ Departemen Obstetri dan Ginekologi, Fakultas Kedokteran, Kesehatan Masyarakat dan Keperawatan UGM \\ Korespondensi: irxan.bob@gmail.com
}

Submisi: 13 Januari 2021; Revisi: 18 Januari 2021; Penerimaan: 22 Januari 2021

\begin{abstract}
Background: Prognostic factors for ovarian cancer include residual tumor and chemotherapy response, but these parameters are not sufficient to predict ovarian cancer prognoses. A new approach such as mGPS that use a combination of CRP and albumin can be used to assess an inflammatory response. With $\mathrm{mGPS}$, an elevated CRP value and hypoalbuminemia are poor prognosis.

Objective: To investigate the effect of mGPS on histopathologic staging and grading of ovarian cancer.

Method: The study design was a cross sectional study. The population of this study were patients with suspected ovarian cancer who underwent laparotomy surgical staging at RSUP Dr. Sardjito. The samples were patients with suspected ovarian cancer that have examined the $h s$-CRP level and albumin level preoperative,then underwent laparotomy surgical staging with histopathological results epithelial ovarian cancer. Data were analyzed using Chi Square test and logistic regression.

Results and Discussion: there were 57 subjects with epithelial ovarian cancer consisting of 25 subjects (43.86\%) with high mGPS and 32 subjects (56.14\%) with low mGPS. The value of mGPS is associated with the stage of ovarian cancer $(p=0.000 ; R P=4.000 \mathrm{Cl} 95 \%=2.195-7.289)$. The results of the multivariate analysis showed that the most important factor in determining the stage was mGPS $(p=0.000 ; \mathrm{RP}=3.81895 \% \mathrm{Cl}=1.544-6.092)$. While the most important factor in determining histopathologic grading of ovarian cancer was the type of ovarian tumor $(p=0.000 ; R P=7.33995 \%$ $\mathrm{Cl}=4.960-9.718)$.
\end{abstract}

Conclusion: There was an association between mGPS and the stage of ovarian cancer. The histopathologic grading was not influenced by mGPS, but was influenced by the type of ovarian tumor.

Keywords: mGPS; Stage; Histopathologic grading; Ovarian Cancer; Epithelial Type

\section{ABSTRAK}

Latar Belakang: Faktor prognosis kanker ovarium meliputi volume residual tumor dan respon terhadap kemoterapi, namun kedua parameter ini dinilai belum cukup signifikan memprediksi prognosis kanker ovarium secara akurat. Beberapa pendekatan baru seperti mGPS yang menggunakan kombinasi CRP dan albumin dapat digunakan untuk menilai adanya respon inflamasi. Dengan $m G P S$, adanya kenaikan nilai CRP dan kondisi hipoalbuminemia menjadi pertanda prognosis yang buruk.

Tujuan: untuk mengetahui pengaruh mGPS pada stadium dan derajat diferensiasi kanker ovarium.

Metode: rancangan penelitian adalah cross sectional study. Populasi penelitian adalah pasien tumor ovarium curiga ganas yang akan menjalani laparotomi pengangkatan massa tumor di RSUP Dr. Sardjito. Sampel penelitian adalah penderita tumor ovarium curiga ganas yang telah dilakukan pemeriksaan $h s$-CRP dan albumin preoperatif dan telah menjalani laparotomi pengangkatan massa tumor dengan hasil histopatologi kanker ovarium epitel. Data dianalisis dengan uji Chi Square dan regresi logistk.

Hasil dan Pembahasan: didapatkan 57 subjek dengan kanker ovarium tipe epitel yang terdiri dari 25 subjek $(43,86 \%)$ dengan nilai $m G P S$ yang tinggi dan 32 subjek $(56,14 \%)$ dengan $m G P S$ yang rendah. Nilai $m G P S$ memiliki pengaruh terhadap stadium kanker ovarium $(p=0,000 ; \mathrm{RP}=4,000 \mathrm{Cl} 95 \%$ $=2,195-7,289)$. Dari hasil analisis multivariat menunjukkan faktor yang paling berperan menentukan stadium adalah $m G P S(p=0,000 ; \operatorname{RP}=3,818$ $C / 95 \%=1,544-6,092)$. Sedangkan faktor yang paling berperan menentukan derajat diferensiasi adalah tipe tumor ovarium $(p=0,000 ; \mathrm{RP}=7,339 \mathrm{Cl}$ $95 \%=4,960-9,718)$.

Kesimpulan: terdapat hubungan antara nilai $m G P S$ dengan stadium kanker ovarium tipe epitel. Derajat diferensiasi kanker ovarium tidak dipengaruhi oleh nilai $m G P S$, tetapi dipengaruhi oleh tipe tumor ovarium.

Kata Kunci: mGPS; Stadium; Derajat Diferensiasi; Kanker Ovarium; Tipe Epitel 


\section{PENDAHULUAN}

Hipotesis tentang etiologi kanker ovarium diantaranya dikenal dengan hipotesis ovulasi yang terus menerus, hipotesis gonadotropin, hipotesis hormonal, dan hipotesis inflamasi. ${ }^{1}$ Hipotesis inflamasi dimulai dari adanya asumsi bahwa terjadinya kanker ovarium disebabkan respon terhadap kerusakan genetik yang disebabkan faktorfaktor inflamasi, seperti berasal dari lingkungan, endometriosis, infeksi saluran genital, atau proses ovulasi itu sendiri. ${ }^{2}$ Inflamasi memegang peranan dalam fisiologi kanker, bisa sebagai pemicu karsinogenesis, diferensiasi, dan pertumbuhan tumor primer. Respon inflamasi sangat erat kaitannya dengan fisiologi kanker, banyak penelitian yang meneliti respon inflamasi untuk luaran kanker. Untuk operasi kanker, Systemic Inflammatory Response (SIR) telah menunjukkan peran sebagai faktor prognosis yang penting dihubungkan dengan rendahnya angka harapan hidup paska operatif pada beberapa jenis kanker. ${ }^{3}$

Faktor prognosis kanker ovarium yang diketahui selama ini meliputi volume residual tumor dan respon terhadap kemoterapi namun kedua parameter ini dinilai belum cukup signifikan memprediksi prognosis kanker ovarium secara akurat. Oleh karena itu beberapa pendekatan baru untuk penilaian prognosis kanker ovarium preoperatif sangat diperlukan. Dari beberapa penelitian berbasis inflamasi seperti $N L R$ dan $P L R$, Glasgow Prognostic Score (GPS) merupakan sistem penilaian yang sudah divalidasi. Sehingga bisa dipakai untuk pemeriksaan klinis rutin pada pasien kanker (terutama karena hubungannya dengan kondisi kaheksia dan buruknya status performa), sehingga GPS dapat dipakai untuk mendeteksi kondisi inflamasi serta status nutrisi pasien dan akan menempatkan inflamasi sebagai target terapi masa depan, yang memungkinkan untuk menunda onset kaheksia dan atau kematian pasien kanker. ${ }^{4}$ Modified Glasgow Prognostic Score (mGPS) menggunakan kombinasi $C R P$ dan albumin sebagai parameter untuk menilai adanya respon inflamasi. Peningkatan CRP dan kondisi hipoalbuminemia bisa mengidentifikasi pasien dengan prognosis lebih jelek dan juga bisa membantu kita untuk menentukan target terapi yang lebih baik. ${ }^{5}$
Pada penelitian terhadap 216 pasien kanker ovarium pada seluruh stadium didapatkan bahwa nilai GPS preoperatif yang tinggi dapat menjadi indikator prognosis yang buruk pada pasien kanker ovarium baik stadium awal maupun stadium lanjut pada seluruh tipe kanker ovarium epitel. Dengan kata lain GPS preoperatif dapat memprediksi progression-free survival (PFS) dan overall survival (OS) pada seluruh kasus kanker ovarium tipe epitel. ${ }^{6}$ Sedangkan penelitian lain menyatakan bahwa $m G P S$ tidak memiliki hubungan dengan stadium dan keberhasilan operasi kanker ovarium tipe epitel. Namun didapatkan hubungan yang bermakna antara $m G P S$ dengan derajat diferensiasi kanker ovarium tipe epitel. ${ }^{7}$

Kanker ovarium menempati urutan kedua dari 10 kasus kanker pada wanita yang terdiagnosis dari tahun 2008-2014 di RSUP Dr. Sardjito. Sehingga pada penelitian ini kamii ingin mengetahui hubungan antara peningkatan nilai $m G P S$ pada stadium dan derajat diferensiasi yang terlihat pada pasien kanker ovarium di RSUP Dr. Sardjito, Yogyakarta.

\section{METODE}

Penelitian ini menggunakan rancangan cross sectional yang dianalisis dengan menilai hubungan antara variabel. Populasi penelitian adalah pasien tumor ovarium curiga ganas yang akan menjalani operasi laparatomi pengangkatan massa tumor di RSUP Dr. Sardjito, Yogyakarta. Sampel penelitian adalah sebagian populasi yang memenuhi kriteria inklusi. Penelitian ini dilakukan di RSUP Dr. Sardjito, Yogyakarta. Waktu penelitian dimulai setelah surat kelayakan etik penelitian diterbitkan. Kriteria inklusi adalah pasien tumor ovarium curiga ganas yang telah menjalani laparatomi pengangkatan massa tumor di RSUP Dr. Sardjito, Yogyakarta dan sudah mendapatkan lembar persetujuan sebagai sampel penelitian. Kriteria ekslusi adalah: penderita dalam kondisi terinfeksi (virus, bakteri) dinilai dengan gejala klinis dan kriteria laboratorium, penderita dengan riwayat penyakit inflamasi, seperti riwayat penyakit SLE, penyakit jantung koroner dan pasien dengan hasil histopatologi kanker ovarium tipe non epitel.

Prosedur penelitian ini dimulai dengan pemberian inform consent terhadap seluruh 
penderita tumor ovarium curiga ganas yang akan menjalani laparatomi pengangkatan massa tumor kemudian dilakukan pengambilan darah vena di laboratorium RSUP Dr. Sardjito, Yogyakarta untuk menilai kadar $h s-C R P$ dan albumin preoperatif dalam serum Setelah operasi dilakukan dan didapatkan hasil histopatologi kanker ovarium epitel, pasien dijadikan sampel penelitian. Kadar $h s-C R P$ dan albumin pasien dengan hasil histopatologi kanker ovarium epitel lalu dinilai sesuai dengan tabel modified Glasgow Prognostic Score. Nilai modified Glasgow Prognostic Score yang diperoleh lalu dicatat untuk masing- masing pasien kemudian dinilai sesuai dengan stadium dan derajat diferensiasi histopatologi pasien. Data dianalisis dengan uji Chi Square dan secara multivariat dengan regresi logistk.

\section{HASIL DAN PEMBAHASAN}

Sampel penelitian yang berhasil dikumpulkan oleh peneliti berjumlah 57 sampel. Sumber data penelitian ini adalah rekam medik pasien RSUP Dr. Sardjito dengan kanker ovarium tipe epitel pada bulan September 2019-Juli 2020. Karakteristik pasien kanker ovarium epitel terangkum dalam Tabel 1.

Tabel 1. Karakteristik Pasien Kanker Ovarium Tipe Epitel

\begin{tabular}{lcc}
$\quad$ Variabel & $\mathrm{n}$ & $\%$ \\
$\begin{array}{l}\text { mGPS } \\
\text { Tinggi }\end{array}$ & 25 & 43,86 \\
Rendah & 32 & 56,14 \\
Usia & & \\
$\quad>40$ Tahun & 49 & 85,96 \\
$\quad<40$ Tahun & 8 & 14,04 \\
\hline
\end{tabular}

\begin{tabular}{lrc}
\multicolumn{1}{c}{ Variabel } & $n$ & $\%$ \\
IMT & & \\
$\quad$ Underweight & 6 & 10,53 \\
$\quad$ Tidak Underweight & 51 & 89,47 \\
Paritas & & \\
$\quad$ Virgo \& Nulipara & 11 & 19,30 \\
$\quad$ Multigravida & 46 & 80,70 \\
Status Menopause & & \\
$\quad$ Menopause & 36 & 63,16 \\
$\quad$ Belum & 21 & 36,84 \\
Tipe Tumor Ovarium & & \\
$\quad$ Tipe 2 & 35 & 61,40 \\
$\quad$ Tipe 1 & 22 & 38,60 \\
Stadium kanker & & \\
Lanjut & 33 & 57,89 \\
$\quad$ Awal & 24 & 42,11 \\
Derajat Differensiasi & & \\
$\quad$ G3 & & \\
$\quad$ G1-G2 & 36 & 63,16 \\
\hline
\end{tabular}

Dari 57 pasien atau subjek penelitian, mayoritas pasien kanker ovarium pada penelitian ini termasuk dalam tumor ovarium tipe 2 yang berjumlah 35 subjek dan berkorelasi dengan stadium kanker ovarium terbanyak yaitu penderita stadium lanjut (33 subjek) serta subjek dengan derajat diferensiasi buruk merupakan gambaran histopatologis yang terbanyak (36 subjek).

Berdasarkan hasil analisis dengan uji ChiSquare untuk menguji hubungan antara mGPS dan stadium kanker diperoleh nilai $p<0,05$ dan nilai RP (Rasio Prevalensi) (Cl 95\%)>1, dengan hal ini dapat disimpulkan bahwa baik secara statistik maupun klinis terdapat hubungan yang signifikan anatar mGPS dan stadium kanker (Tabel 2).

Tabel 2. Analisis Bivariat Hubungan antara mGPS dan Stadium

\begin{tabular}{|c|c|c|c|c|c|c|c|}
\hline \multirow{2}{*}{ Variabel } & \multicolumn{4}{|c|}{ Stadium } & \multirow{2}{*}{$P$} & \multirow{2}{*}{$\mathbf{R P}$} & \multirow{2}{*}{$95 \% \mathrm{Cl}$} \\
\hline & Lanjut & $\%$ & Awal & $\%$ & & & \\
\hline \multicolumn{8}{|l|}{ mGPS } \\
\hline Tinggi & 25 & 100,00 & 0 & 0,00 & 0,000 & 4,000 & $2,195-7,289$ \\
\hline Rendah & 8 & 25,00 & 24 & 75,00 & & 1 & \\
\hline
\end{tabular}

Tabel 3. Analisis Bivariat Hubungan antara mGPS dan Derajat Differensiasi

\begin{tabular}{|c|c|c|c|c|c|c|c|}
\hline \multirow{2}{*}{ Variabel } & \multicolumn{4}{|c|}{ Derajat Differensiasi } & \multirow{2}{*}{$\mathbf{P}$} & \multirow{2}{*}{$\mathbf{R P}$} & \multirow{2}{*}{$95 \% \mathrm{Cl}$} \\
\hline & G3 & $\%$ & G1-G2 & $\%$ & & & \\
\hline \multicolumn{8}{|l|}{ mGPS } \\
\hline Tinggi & 19 & 76,00 & 6 & 24,00 & 0,076 & 1,431 & $0,966-2,119$ \\
\hline Rendah & 17 & 53,12 & 15 & 46,88 & & 1 & \\
\hline
\end{tabular}


Tabel 4. Analisis Bivariat Hubungan antara Variabel luar dan Stadium

\begin{tabular}{|c|c|c|c|c|c|c|c|}
\hline \multirow{2}{*}{ Variabel } & \multicolumn{4}{|c|}{ Stadium } & \multirow{2}{*}{$P$} & \multirow{2}{*}{$\mathbf{R P}$} & \multirow{2}{*}{$95 \% \mathrm{Cl}$} \\
\hline & Lanjut & $\%$ & Awal & $\%$ & & & \\
\hline \multicolumn{8}{|l|}{ Usia } \\
\hline$\geq 40$ Tahun & 31 & 63,27 & 18 & 36,73 & 0,059 & 2,531 & $0,748-8,563$ \\
\hline$<40$ Tahun & 2 & 25,00 & 6 & 75,00 & & 1 & \\
\hline \multicolumn{8}{|l|}{ IMT } \\
\hline Underweight & 4 & 66,67 & 2 & 33,33 & 1,000 & 1,172 & $0,634-2,167$ \\
\hline Tidak Underweight & 29 & 56,86 & 22 & 43,14 & & 1 & \\
\hline \multicolumn{8}{|l|}{ Paritas } \\
\hline Virgo \& Nulipara & 7 & 63,64 & 4 & 36,36 & 0,745 & 1,126 & $0,674-1,882$ \\
\hline Multigravida & 26 & 56,52 & 20 & 43,48 & & 1 & \\
\hline \multicolumn{8}{|l|}{ Status Menopause } \\
\hline Menopause & 25 & 69.44 & 11 & 30,56 & 0,021 & 1,823 & $1,014-3,278$ \\
\hline Belum & 8 & 38,10 & 13 & 61,90 & & 1 & \\
\hline \multicolumn{8}{|l|}{ Tipe Tumor Ovarium } \\
\hline Tipe 2 & 26 & 74,29 & 9 & 25,71 & 0,002 & 2,335 & $1,229-4,437$ \\
\hline Tipe 1 & 7 & 31,82 & 15 & 68,18 & & 1 & \\
\hline
\end{tabular}

Tabel 5. Analisis Bivariat Hubungan antara Variabel luar dan Derajat Differensiasi

\begin{tabular}{|c|c|c|c|c|c|c|c|}
\hline \multirow{2}{*}{ Variabel } & \multicolumn{4}{|c|}{ Derajat Differensiasi } & \multirow{2}{*}{$\boldsymbol{P}$} & \multirow{2}{*}{$\mathbf{R P}$} & \multirow{2}{*}{$95 \% \mathrm{Cl}$} \\
\hline & G3 & $\%$ & $\mathbf{G 1 - G 2}$ & $\%$ & & & \\
\hline \multicolumn{8}{|l|}{ Usia } \\
\hline$\geq 40$ Tahun & 34 & 69,39 & 15 & 30,61 & 0,099 & 2,776 & $0,824-9,350$ \\
\hline$<40$ Tahun & 2 & 25,00 & 6 & 75,00 & & 1 & \\
\hline \multicolumn{8}{|l|}{ IMT } \\
\hline Underweight & 4 & 66,67 & 2 & 33,33 & 1,000 & 1,063 & $0,581-1,944$ \\
\hline Tidak Underweight & 32 & 62,75 & 19 & 37,25 & & 1 & \\
\hline \multicolumn{8}{|l|}{ Paritas } \\
\hline Virgo \& Nulipara & 7 & 63,64 & 4 & 36,36 & 1,000 & 1,009 & $0,613-1,662$ \\
\hline Multigravida & 29 & 63,04 & 17 & 36,96 & & 1 & \\
\hline \multicolumn{8}{|l|}{ Status Menopause } \\
\hline Menopause & 26 & 72,22 & 10 & 27,78 & 0,063 & 1,517 & $0,927-2,481$ \\
\hline Belum & 10 & 47,62 & 11 & 52,38 & & 1 & \\
\hline \multicolumn{8}{|l|}{ Tipe Tumor Ovarium } \\
\hline Tipe 2 & 33 & 94,29 & 2 & 5,71 & 0,000 & 6,914 & $2,408-19,853$ \\
\hline Tipe 1 & 3 & 13,64 & 19 & 86,36 & & 1 & \\
\hline
\end{tabular}

Tabel 6. Analisis Bivariat Hubungan antara Variabel luar dan mGPS

\begin{tabular}{|c|c|c|c|c|c|c|c|}
\hline \multirow{2}{*}{ Variabel } & \multicolumn{4}{|c|}{ mGPS } & \multirow{2}{*}{$P$} & \multirow{2}{*}{$\mathbf{R P}$} & \multirow{2}{*}{$95 \% \mathrm{Cl}$} \\
\hline & Tinggi & $\%$ & Rendah & $\%$ & & & \\
\hline \multicolumn{8}{|l|}{ Usia } \\
\hline$\geq 40$ Tahun & 23 & 46,94 & 26 & 53,06 & 0,444 & 1,878 & $0,545-6,466$ \\
\hline$<40$ Tahun & 2 & 25,00 & 6 & 75,00 & & 1 & \\
\hline \multicolumn{8}{|l|}{ IMT } \\
\hline Underweight & 3 & 50,00 & 3 & 50,00 & 1,000 & 1,159 & $0,491-2,739$ \\
\hline Tidak Underweight & 22 & 43,14 & 29 & 56,86 & & 1 & \\
\hline \multicolumn{8}{|l|}{ Paritas } \\
\hline Virgo \& Nulipara & 7 & 63,64 & 4 & 36,36 & 0,184 & 1,626 & $0,916-2,887$ \\
\hline Multigravida & 18 & 39,13 & 28 & 60,87 & & 1 & \\
\hline
\end{tabular}




\begin{tabular}{|c|c|c|c|c|c|c|c|}
\hline \multirow{2}{*}{ Variabel } & \multicolumn{4}{|c|}{ mGPS } & \multirow{2}{*}{$\boldsymbol{P}$} & \multirow{2}{*}{$\mathbf{R P}$} & \multirow{2}{*}{$95 \% \mathrm{Cl}$} \\
\hline & Tinggi & $\%$ & Rendah & $\%$ & & & \\
\hline \multicolumn{8}{|l|}{ Status Menopause } \\
\hline Menopause & 19 & 52,87 & 17 & 47,22 & 0,076 & 1,847 & $0,878-3,885$ \\
\hline Belum & 6 & 28,57 & 15 & 71,43 & & 1 & \\
\hline \multicolumn{8}{|c|}{ Tipe Tumor Ovarium } \\
\hline Tipe 2 & 20 & 57,14 & 15 & 42,86 & 0,011 & 2,514 & $1,105-5,721$ \\
\hline Tipe 1 & 5 & 22,73 & 17 & 77,27 & & 1 & \\
\hline
\end{tabular}

Hasil uji Chi Square hubungan antara mGPS dan derajat diferensiasi diperoleh nilai $p>0,05$ (RP 1,431 $95 \% \mathrm{Cl} 0,966-2,1229)$ yang menunjukkan bahwa tidak terdapat hubungan yang bermakna secara statistik antara $m G P S$ dengan derajat diferensiasi (Tabel 3). Hasil analisis dengan uji Chi-Square untuk menguji hubungan antara variabel luar dan stadium kanker menunjukkan bahwa variabel status menopause $(p=0,021)$ dan tipe tumor $(p=0,002)$ mempunyai hubungan yang bermakna baik statistik dan klinis. Sedangkan variabel usia, IMT, dan paritas tidak mempunyai pengaruh terhadap stadium kanker (Tabel 4). Satu-satunya variabel luar yang memiliki hubungan dengan derajat differensiasi hanyalah tipe tumor ovarium $(p=0,000)$ sedangkan usia, IMT, paritas, dan status menopause tidak yakni dengan nilai $p>0,05$ (Tabel 5). Hasil uji hubungan antara variabel luar dan mGPS menunjukkan bahwa hanya tipe tumor ovarium yang memiliki hubungan yang sigifikan dengan $\operatorname{mGPS}(p=0,011)$ sedangkan yang lainnya tidak $(p>0,05)$ (Tabel 6$)$.

Tabel 7. Analisis Multivariat Hubungan mGPS, usia, status menopause, dan tipe tumor ovarium terhadap stadium

\begin{tabular}{lccc}
\multicolumn{1}{c}{ Variabel } & RP & $95 \% \mathrm{Cl}$ & $\boldsymbol{p}$ \\
$\begin{array}{l}\text { mGPS } \\
\text { Tinggi }\end{array}$ & 3,818 & $1,544-6,092$ & 0,000 \\
$\quad$ Rendah & 1 & & \\
$\begin{array}{l}\text { Usia } \\
\geq 40 \text { Tahun }\end{array}$ & 2,343 & $0,022-5,708$ & 0,400 \\
$\quad<40$ Tahun & 1 & & \\
$\begin{array}{l}\text { Status Menopause } \\
\quad \text { Menopause }\end{array}$ & 1,238 & $0,510-2,986$ & 0,678 \\
$\quad$ Belum & 1 & & \\
$\begin{array}{l}\text { Tipe Tumor } \\
\text { Ovarium }\end{array}$ & & & \\
$\quad \begin{array}{l}\text { Tipe 2 } \\
\text { Tipe } 1\end{array}$ & 1,736 & $0,094-3,378$ & 0,255 \\
& 1 & & \\
\hline
\end{tabular}

Tabel 8. Analisis Multivariat Hubungan mGPS, usia, status menopause, dan tipe tumor ovarium terhadap derajat diferensiasi

\begin{tabular}{lccc}
\multicolumn{1}{c}{ Variabel } & RP & $95 \% \mathrm{Cl}$ & $p$ \\
$\begin{array}{l}\text { mGPS } \\
\text { Tinggi }\end{array}$ & 0,680 & $0,621-2,981$ & 0,554 \\
$\quad$ Rendah & 1 & & \\
$\begin{array}{l}\text { Usia } \\
\geq 40 \text { Tahun }\end{array}$ & 2,450 & $0,664-5,564$ & 0,327 \\
$\quad<40$ Tahun & 1 & & \\
$\begin{array}{l}\text { Status Menopause } \\
\text { Menopause }\end{array}$ & 0,776 & $0,537-3,089$ & 0,713 \\
$\quad$ Belum & 1 & & \\
$\begin{array}{l}\text { Tipe Tumor } \\
\text { Ovarium } \\
\text { Tipe 2 }\end{array}$ & & & \\
$\quad$ Tipe 1 & 7,339 & $4,960-9,718$ & 0,000 \\
\hline
\end{tabular}

Hasil multivariat menunjukkan bahwa hanya mGPS memiliki hubungan yang signifikan dengan stadium dengan nilai $p=0,000$ dan $\mathrm{RP}(\mathrm{Cl} 95 \%)$ terbesar yakni 3,818 $(1,544-6,092)$ (tabel 7). Nilai $p$ dari hasil uji regresi logistik tidak jauh berbeda dengan nilai $p$ dari hasil uji bivariat, di mana mGPS mempunyai hubungan yang sangat signifikan bermakna dengan stadium kanker ovarium. Tipe tumor ovarium memiliki hubungan yang signifikan dengan derajat diferensiasi dengan nilai $p=0,000$ dan RP (Cl 95\%) terbesar yakni 7,339 $(4,960-9,718)$ (Tabel 8). Nilai $p$ dari hasil uji regresi logistik tidak jauh berbeda dengan nilai $p$ dari hasil uji bivariat, di mana tipe tumor ovarium mempunyai hubungan yang sangat signifikan bermakna dengan derajat diferensiasi kanker ovarium. Peneliti juga menghitung kekuatan dari penelitian ini yang besarnya adalah $68 \%$.

Penelitian sebelumnya telah menunjukkan peran CRP dalam berbagai tumor padat termasuk prostat, paru-paru, kolorektal dan kanker ovarium. Terdapat bukti bahwa Glasgow Prognostic Score 
(GPS) yang merupakan skor prognosis yang berbasis inflamasi dengan menggunakan 2 protein yang konstitutif yaitu CRP dan albumin, merupakan salah satu model prognosis yang dapat digunakan pada beberapa kasus kanker. Namun, peran prognostik GPS pada kanker ovarium masih belum begitu jelas. Dalam sebuah studi didapatkan bahwa nilai GPS yang lebih tinggi berkorelasi signifikan dengan klinikopatologis, seperti perfroma status yang buruk, kejadian karsinoma serosa dan derajat diferensiasi yang buruk. ${ }^{8}$

Mayoritas pasien kanker ovarium pada penelitian ini termasuk dalam tumor ovarium tipe 2 yang berjumlah 35 subjek dan berkorelasi dengan stadium kanker ovarium terbanyak yaitu penderita stadium lanjut (33 subjek) serta subjek dengan derajat diferensiasi buruk merupakan gambaran histopatologis yang terbanyak (36 subjek). Hal ini sesuai dengan teori Kurman dan Shih (2010) yang menyatakan tumor ovarium tipe 2 merupakan jenis tumor yang bertumbuh secara cepat, sangat agresif dan biasanya sudah berada pada stadium lanjut sejak awal kemunculannya. ${ }^{9}$

Pada analisis bivariat ditemukan adanya hubungan yang signifikan bermakna antar mGPS dan stadium baik secara statistik maupun klinis, yaitu $p=0,000$ dan $\mathrm{RP}=4,000$ dengan $\mathrm{Cl} 95 \%=2,195-$ 7,289. Hal ini dapat dimaknai bahwa prevalensi kanker stadium lanjut pada pasien dengan $m G P S$ tinggi lebih besar daripada pasien dengan mGPS rendah atau pasien kanker ovarium epitel dengan mGPS tinggi memiliki kemungkinan mengalami kanker ovarium epitel stadium lanjut sebesar 4 kali dibandingkan pasien dengan $m G P S$ rendah. Hal ini sejalan dengan penelitian sebelumnya terhadap pasien kanker ovarium epitel di mana dijumpai hasil yang bermakna untuk hubungan stadium berdasarkan FIGO dan skor mGPS $(p<0,001)$. PFS yang rendah pada stadium awal, lanjut dan seluruh stadium kanker ovarium serta OS yang rendah pada stadium lanjut dan seluruh stadium sering dijumpai pada nilai GPS preoperatif yang tinggi. Oleh karena itu penentuan GPS preoperatif dinilai berguna untuk menentukan prognosis pasien kanker ovarium epitel pada seluruh stadium termasuk stadium awal. ${ }^{6}$ Penelitian lain juga mendapatkan adanya hubungan yang signifikan antara stadium dengan nilai GPS preoperatif pada kanker endometrium. ${ }^{10}$ Perbedaannya dengan penelitian saat ini adalah kami hanya menilai luaran dari stadium dan derajat diferensiasi histopatologi kanker ovarium sementara penelitian sebelumnya menilai angka ketahanan hidup pasien kanker.

Pada penelitian ini didapatkan bahwa tidak terdapat hubungan antara mGPS dan derajat differensiasi dengan nilai $p>0,05$. Hal ini sejalan dengan penelitian yang menilai mGPS pada pasien kanker vulva dimana derajat diferensiasi tidak memiliki hubungan bermakna terhadap nilai $m G P S$ $(p=0,8) .{ }^{11}$ Penelitian lainnya mengenai penggunaan GPS/mGPS sebagai prediktor prognosis kanker kolorektal juga mendapatkan hasil bahwa derajat diferensiasi tidak bermakna secara signifikan terhadap GPS/mGPS $(p=0,127$ dan $p=0,166) .{ }^{12}$ Namun hasil ini bertolak belakang dengan dua penelitian sebelumnya yang mendapatkan hubungan yang bermakna antara $m G P S$ dengan derajat diferensiasi histopatologi kanker ovarium epitel ( $p=0,001$ dan $p=0,03$ ). Semakin tinggi nilai $m G P S$ maka semakin buruk derajat diferensiasi pada kanker ovarium. ${ }^{5,7}$ Walaupun $m G P S$ bermakna secara klinis terhadap derajat diferensiasi kanker ovarium namun secara statistik tidak ditemukan hubungan yang signifikan pada penelitian ini.

Hasil analisis dengan uji Chi-Square untuk menguji hubungan antara variabel luar dan stadium kanker menunjukkan bahwa variabel status menopause $(p=0,021)$ dan tipe tumor ovarium $(p=0,002)$ mempunyai hubungan yang bermakna baik statistik dan klinis. Hal ini dapat dimaknai bahwa prevalensi kanker stadium lanjut pada wanita menopause lebih besar daripada wanita belum menopause atau wanita menopause memiliki kemungkinan mengalami kanker ovarium epitel stadium lanjut sebesar 1,823 kali dibandingkan wanita belum menopause. Hal ini sejalan dengan penelitian sebelumnya di tahun 2019 bahwa prevalensi kanker ovarium stadium lanjut (Stadium FIGO III-IV) lebih banyak ditemukan pada wanita postmenopause dibandingkan dengan wanita premenopause $(p=0,016){ }^{13}$

Pada penelitian ini juga didapatkan prevalensi terjadinya kanker stadium lanjut pada tumor ovarium tipe 2 lebih besar daripada tipe 1 atau tumor 
ovarium tipe 2 memiliki kemungkinan menyebabkan kanker ovarium epitel stadium lanjut sebesar 2,335 kali dibandingkan tipe 1 . Hal ini sesuai dengan teori yang diajukan oleh Kurman dan Shih yang membagi kanker ovarium berdasarkan gambaran klinis, patologi dan studi molekuler genetik menjadi 2 tipe , tipe 1 dan tipe 2. Tipe I adalah tumor yang tumbuh secara lambat, masih terbatas pada ovarium pada saat diagnosis dan berasal dari lesi prekursor yang disebut dengan tumor borderline. Tipe II adalah jenis tumor yang bertumbuh secara cepat, sangat agresif dengan lesi prekursor yang masih belum jelas dan biasanya sudah berada pada stadium lanjut sejak awal kemunculannya. ${ }^{9,14}$ Pada penelitian ini variabel usia, IMT, dan paritas tidak mempunyai pengaruh terhadap stadium kanker.

Satu-satunya variabel luar yang memiliki hubungan dengan derajat differensiasi hanyalah tipe tumor ovarium $(p=0,000)$. Hal ini dapat dimaknai bahwa prevalensi derajat diferensiasi buruk (G3) pada kanker ovarium tipe 2 lebih besar daripada kanker ovarium tipe 1 atau kanker ovarium tipe 2 memiliki kemungkinan menyebabkan derajat diferensiasi buruk sebesar 6,914 kali dibandingkan tipe 1. Hal ini sesuai dengan teori yang diajukan oleh Kurman dan Shih pada tahun 2008 yang membagi kanker ovarium berdasarkan gambaran klinis, patologi dan studi molekuler genetik menjadi 2 tipe, tipe 1 dan tipe 2. Tipe 1 meliputi low grade serous, low grade endometrioid, mucinous, clear cell dan tumor Brenner. Termasuk ke dalam grup tipe II ini adalah high grade serous, high grade endometrioid, malignant mixed mesodermal tumor (carcinosarcoma) dan undifferentiated carcinoma. ${ }^{9,14}$ Pada penelitian ini usia, IMT, paritas, dan status menopause tidak mempunyai pengaruh terhadap derajat diferensiasi kanker ovarium.

Hasil uji hubungan antara variabel luar dan mGPS menunjukkan bahwa hanya tipe tumor ovarium yang memiliki hubungan yang sigifikan dengan mGPS $(p=0,011)$ sedangkan yang lainnya tidak $(p>0,05)$. Hal ini dapat dimaknai bahwa prevalensi $m G P S$ yang tinggi pada kanker ovarium tipe 2 lebih besar daripada kanker ovarium tipe 1 atau kanker ovarium tipe 2 memiliki skor mGPS yang tinggi sebesar 6,914 kali dibandingkan tipe 1. Hasil penelitian ini sejalan dengan penelitian sebelumnya yang menemukan hubungan yang signifikan antara nilai GPS preoperatif yang tinggi dengan histologi kanker ovarium $(p=0,001){ }^{6}$

Analisis multivariat dengan regresi logistik untuk menilai hubungan keempat variable secara bersamaan atau spontan terhadap stadium. Hasil analisis ini menunjukkan adanya hubungan yang kuat atau signifikan bermakna baik secara statistik maupun klinis antara nilai $m G P S$ yang tinggi dan stadium kanker ovarium dengan nilai $p=0,000 \mathrm{RP}$ (Cl 95\%) terbesar yakni 3,818 (1,544-6,092). Nilai mGPS yang tinggi menjadi faktor risiko terjadinya stadium lanjut pada pasien, dimana pasien dengan nilai mGPS yang tinggi berisiko sebesar 3,8 kali mengalami stadium lanjut dibandingkan dengan pasien dengan nilai $m G P S$ yang rendah. Dengan kata lain GGPS merupakan faktor independen terhadap stadium kanker ovarium. Walaupun usia, status menopause dan tipe tumor ovarium bermakna dari analisis bivariat namun pada analisis multivariat ketiga variable ini tidak terdapat hubungan yang bermakna terhadap stadium kanker ovarium hal ini karena variabel tersebut dipengaruhi oleh variabel yang lain.

Hasil analisis multivariat dengan regresi logistik antara keempat variabel terhadap derajat diferensiasi menunjukkan adanya hubungan yang kuat atau signifikan bermakna baik secara statistik maupun klinis antara tumor ovarium tipe 2 dan derajat diferensiasi kanker ovarium dengan nilai $p=0,000$ dan RP $(\mathrm{Cl} 95 \%)=7,339 \quad(4,960-9,718)$. Tumor ovarium tipe 2 menjadi faktor risiko terhadap derajat diferensiasi, dimana pasien dengan tumor ovarium tipe 2 berisiko sebesar 7,3 kali memiliki derajat diferensiasi buruk pada kanker ovarium dibandingkan tumor ovarium tipe 1 . Tumor ovarium tipe 2 memiliki aktivitas mitosis yang lebih tinggi dengan sel berinti banyak dan dengan sitologi atipikal yang berat sehingga cenderung berdiferensiasi buruk dan agresif. ${ }^{9,14}$ Sedangkan mGPS, usia, status menopause tidak terdapat hubungan yang bermakna terhadap derajat diferensiasi.

Pada uji hubungan antara mGPS dan derajat diferensiasi terdapat perbedaan yang besar antara nilai $p$ dan RP pada analisis bivariat (Chi Square) dan nilai $p$ dan RP pada analisis multivariat (regresi logistik). Hasil analisis bivariat antara $m G P S$ dan 
derajat diferensiasi yakni dengan nilai $p=0,076$ dan $R P=1,431$. Sedangkan hasil analisis multivariat yakni nilai $p=0,554$ dan $\mathrm{RP}=0,680$. Meskipun kedua nilai ini tidak signifikan baik secara statistik maupun klinis tetapi perbedaan ini menunjukkan bahwa secara parsial subjek dengan mGPS tinggi memiliki kemungkinan mengalami derajat differensiasi buruk lebih besar yakni sebesar 1,4 kali. Akan tetapi ketika diuji secara bersamaan dengan variabel lain yakni usia, menopause, dan tipe tumor ovarium, terjadi penurunan nilai baik $p$ maupun RP dari mGPS. Hal ini menunjukkan bahwa mGPS bukanlah faktor penyebab utama terhadap kejadian derajat diferensiasi buruk pada subjek atau tidak memberikan pengaruh yang besar terhadap derajat diferensiasi dibandingkan dengan variabel lain.

Penelitian ini memiliki beberapa kekurangan yang bisa diperbaiki pada penelitian ke depan untuk memvalidasi dan mengembangkan hasil dari penelitian ini. Jumlah subjek pada penelitian ini tidak mencukupi jumlah sampel, dikarenakan keterbatasan waktu dan biaya, sehingga terdapat bias sampel. Data sekunder pada penelitian ini diperoleh dari rekam medis, sehingga hasil penelitian sangat dipengaruhi oleh kelengkapan data yang tertulis pada rekam medis. Pada penelitian ini juga tidak menilai faktor prognosis lain seperti volume residu tumor, adanya asites dan status performa yang juga merupakan faktor prognosis independen pada kanker ovarium.

\section{KESIMPULAN DAN SARAN}

Skor mGPS memiliki hubungan terhadap stadium kanker ovarium baik secara statistik maupun klinis dimana pasien dengan nilai $m G P S$ yang tinggi berisiko sebesar 3,8 kali mengalami stadium lanjut dibandingkan dengan pasien dengan nilai $m G P S$ yang rendah. Sedangkan skor $m G P S$ tidak memiliki hubungan yang bermakna terhadap derajat diferensiasi kanker ovarium.

Walaupun secara klinis mGPS memiliki hubungan bermakna dengan derajat diferensiasi namun secara statistik hubungan tersebut tidak signifikan dengan kekuatan penelitian $68 \%$ sehingga diperlukan penambahan sampel sampai memenuhi sampel minimal dengan proporsi sama pada kedua kelompok. Untuk meminimalkan bias data, maka sebaiknya rancangan studi penelitian dilakukan dengan kohort prospektif.

\section{DAFTAR PUSTAKA}

1. Suhonen, K. Prognostic Role of Cell Adhesion Factors and Angiogenesis in Epithelial Ovarian Cancer. Doctoral Dissertation. Kuopio: University of Kuopio. Clinical Medicine, 2007

2. Aziz MF, Andrijono, Saifuddinn AB. Buku acuan Nasional Onkologi Ginekologi. Yayasan Bina Pustaka Sarwono Prawirohardjo. Departemen Ginekologi dan ginekologi fakultas kedokteran Indonesia. Edisi pertama. 2006; $469-527$

3. Bugada, D., Allegri, M., Lavand'Homme, P., De Kock, M., \& Fanelli, G. (2014). Inflammation-based scores: A new method for patient-targeted strategies and improved perioperative outcome in cancer patients. BioMed Research International, 2014. https://doi. org/10.1155/2014/142425

4. Hashem, T.A., Shehata, M.A., Alhassanin, S.A., ElMenshawy, S.M., Gohar,

5. Sharma, R., Hook, J., Kumar, M., \& Gabra, H. (2008). Evaluation of an inflammation-based prognostic score in patients with advanced ovarian cancer. European Journal of Cancer, 44(2), 251-256. https:// doi.org/10.1016/j.ejca.2007.11.011

6. S.F.(2020). The prognostic value of Glasgow prognostic score in epithelial ovarian cancer. Menoufia Med J 33:699-705. DOI: 10.4103/mmj. mmj_264_19

7. Omichi, C., Nakamura, K., Haraga, J., Masuyama, H., \& Hiramatsu, Y. (2016). Glasgow prognostic score is an independent marker for poor prognosis with all cases of epithelial ovarian cancer. Cancer Medicine, 5(6), 1074-1080. https://doi.org/10.1002/cam4.681

8. Adella, C.A., Simanjuntak, R.Y., and Adhisty, H.N. Luaran Kanker Ovarium

9. Berdasarkan Modifikasi Glasgow Prognostik Skor, Tesis PPDS I Obstetri dan Ginekologi FK USU. Medan, 2015.

10. Zhu, J., Wang, H., Liu, C. C., Lu, Y., \& Tang, H. (2016). The Glasgow Prognostic Score (GPS) is a novel prognostic indicator in advanced epithelial ovarian cancer: a multicenter retrospective study. Journal of Cancer Research and Clinical Oncology, 142(11), 2339-2345. https://doi.org/10.1007/s00432-0162228-y

11. Kurman, R. J., \& Shih, I. M. (2010). The origin and pathogenesis of epithelial ovarian cancer: A proposed unifying theory. American Journal of Surgical Pathology, 34(3), 433-443. https://doi. org/10.1097/PAS.0b013e3181cf3d79 
12. Nakamura, K., Nakayama, K., Minamoto, T., Ishibashi, T., Sanuki, K., Yamashita, H., Ono, R., Sasamori, H., Komatsu-Fujii, T., Ishikawa, M., \& Kyo, S. (2018). High preoperative Glasgow prognostic score is a negative prognostic factor for patients with endometrial carcinoma. Molecular and Clinical Oncology, 429433. https://doi.org/10.3892/mco.2018.1551

13. Hefler-Frischmuth, K., Seebacher, V., Polterauer, S., Tempfer, C., Reinthaller, A., \& Hefler, L. (2010). The inflammation-based modified Glasgow Prognostic Score in patients with vulvar cancer. European Journal of Obstetrics and Gynecology and Reproductive Biology, 149(1), 102-105. https://doi. org/10.1016/j.ejogrb.2009.12.027

14. Nozoe, T., Matono, R., Ijichi, H., Ohga, T., \& Ezaki, T. (2014). Glasgow prognostic score (GPS) can be a useful indicator to determine prognosis of patients with colorectal carcinoma. International Surgery, 99(4), 512-517. https://doi.org/10.9738/ INTSURG-D-13-00118.1
15. Han, K. H., Park, N. H., Kim, J. J., Kim, S., Kim, H. S., Lee, M., \& Song, Y. S. (2019). The power of the risk of ovarian malignancy algorithm considering menopausal status: A comparison with CA 125 and HE4. Journal of Gynecologic Oncology, 30(6), 1-9. https://doi.org/10.3802/jgo.2019.30.e83

16. Berek JS, Friedlander M, Hacker NF. Epithelial Ovarian, Fallopian Tube, and Peritoneal Cancer, in berek and Hacker's Gynecologic Oncology, 16th Edition. Lippincott Williams \& Wilkins, 2020: 25412619 